\title{
Exploration of Electrochemcially Active Bacterial Strains for Microbial Fuel Cells: An Innovation in Bioelectricity Generation
}

\author{
B.R. Sreelekshmy (iD) \\ Department of Biotechnology, University of Kerala, Kariavattom Campus, Thiruvananthapuram - 695 581, Kerala, \\ India.
}

\begin{abstract}
The field of MFC technology has endured immense development during the past couple of decades. During this period, electrically connected microbial communities (e - communities) were studied extensively which helps the scientists in designing better versions of MFCs. Mixed bacterial culture and sometimes pure culture is widely used as an efficient exoelectrogens for the successful operation of MFCs. As the literature review, many microorganisms belong to firmicutes and actinobacteria phyla and all classes of proteobacteria, archaea are widely used in MFCs for power generation. In addition mixed bacterial culture from anaerobic sludge, industrial wastes etc are also used for enhanced power generation in MFC. In the present paper, we review the prominent exoelectrogens used in MFCs operation an innovation towards bioelectricity generation. Understanding the role and mechanism of electron transfer broaden the exploration of microbes towards waste treatment and simultaneous electricity using MFC technology in various sectors generation. Synergistic and interspecies interaction also helps a lot to improve the current generation in MFC. Recently, many researchers are tried genetic engineering of particular organism and results in enhanced production and accumulation of flavin molecules and thus improved the electricity generation compared to wild type. In the light of specific characters of microorganism, the ecological knowledge of microbial resources is essential for extending the foundation and future developments in MFC. Understanding of bioelectricity production by various exoelectrogens and its changes over time in the MFC opens up a new world to combat excess energy consumption in future.
\end{abstract}

Keywords: Microbial fuel cells, Exoelectrogens, Bioelectricity, Extracellular electron transfer

*Correspondence: b.rsreelekshmy197@gmail.com

(Received: January 02, 2020; accepted: February 06, 2020)

Citation: B.R. Sreelekshmy, Exploration of Electrochemcially Active Bacterial Strains for Microbial Fuel Cells: An Innovation in Bioelectricity Generation, J. Pure Appl. Microbiol., 2020; 14(1): 103-122. https://doi.org/10.22207/JPAM.14.1.12

(C) The Author(s) 2020. Open Access. This article is distributed under the terms of the Creative Commons Attribution 4.0 International License which permits unrestricted use, sharing, distribution, and reproduction in any medium, provided you give appropriate credit to the original author(s) and the source, provide a link to the Creative Commons license, and indicate if changes were made. 


\section{INTRODUCTION}

Richard, E. Smalley (late noble laureate) said that "Energy is the single most important problem facing humanity today." The global energy demand is increasing rapidly, especially in emerging market economies, because of population and economic growth. Recklessness in extracting the fossil fuels from natural sources and lavishness in using them are arguably the two worst ways of fossil fuel abuses. If this situation persists, the exhaustion of fossil fuels would be unavoidable, leading to the global energy crisis, which would affect the world economy as a whole [Alcayde et al., 2018]. These increase in demands and fast dwindling of conventional fossil fuel reserves instigate serious deliberations on the need to target on nonconventional sources of energy. Thus, the researches that aim at developing an alternative source of energy are progressing exponentially to handle the situation of the global energy crisis. One sensible step that can alleviate the crisis to a great extent is the extraction of energy from renewable sources. India is one of the largest producers of energy from renewable sources. As per the 2019 reports, 21\% of the total installed power capacity is generated from renewable energy. Paradoxically, biomass stores in itself, immense energy reserves that can be tapped and channeled only through strategic approach to produce different forms of energy. Production of biogas from biomass is one of the most practiced methods to solve our energy needs. Electricity production from biomass has been realized to be a promising method in the near future. In such rural areas where supplying electricity at subsidized pricing is an excellent problem due to high distribution costs and transmission losses, biomass fuels can be the best cost - effective solution [Logan, 2004].

"Waste to electricity" has become practical to some extent and this technology helps in the reduction of $\mathrm{CO}_{2}$ emission, thereby decreasing global warming. A number of technologies have been developed by various concerns (both private and public) to extract energy from biomass. Among this the use of fuel cell has evolved to be successful for producing energy from biomass. Among fuel cells, Microbial Fuel Cells (MFCs) are economically cheap and alternative forms of bioenergy where electrical energy can be extracted from organic waste matter and renewable biomass by microbial degradation. Such microorganisms are named as exoelectrogens. Most of the microorganism transfers the electrons to the anode through simple respiratory electron transport chain consists of various membrane protein subunits for extracellular electron transfer. Different exoelectrogens exhibits different mechanism of electron transfer, which depends on the many factors. Still comprehensive awareness of electron transfer mechanism that occurring at bacteria - electrode interface in microbial fuel cell that affect the kinetic loss is lacking. In this context, studying microbial interactions with the electrode and their electroactivity could help to improve the exploitation of such microbes for bioelectricity production. In the present review, we tried to explore and introduce some commonly used exoelectrogens (till 2019) and predicted mechanism of electron transfer of commonly used microbes. An extensive scope lies ahead in the scaling up of MFCs, for the large - scale conversion of organic wastes and biomass into electricity, for powering vehicles, mobile electronic devices, and buildings. Thus, the research and development of biomass energy using fuel cell can be a good means of renewable energy, which in future can replace fossil fuels.

\section{Bioelectricity generation from Microbial Fuel Cells} using exoelectrogens as a catalyst

Bacteria can generate electricity; this is a fact known for almost a century [Logan and Regan 2006]. In MFCs, bacteria oxidize organic and inorganic matter to generate electricity [Logan et al., 2006]. A typical MFC consists primarily of 2 chambers - anodic and cathodic chamber which contain anode and cathode respectively. A proton exchange membrane (PEM) is used to separate the two chambers. The anodic chamber consists of microorganisms; a suitable substrate is added to it for the favorable growth of it. These microorganisms degrade the substrate and release electrons that are transported through an external circuit to the cathode. The protons which are generated pass selectively through the PEM. These electrons and protons that are produced due to the microbial metabolism in the anodic chamber travel to the cathode chamber and then produce water by reaction with oxygen [Sharma and $\mathrm{Li}$, 2010]. The electrons can also be transferred to the 
anode with the help of mediators or shuttle system [Rabaey et al., 2004; Rabaey et al., 2005a]. It can be achieved by direct membrane transport [Bond and Lovely, 2003] or by nanowires that are produced by the bacteria [Reguera et al., 2005; Gorby et al., 2006]. Chemical mediators can be added to the MFCs for the production of electricity by bacteria [Park and Zeikus, 1999; Bond et al., 2002]. In some systems, bacteria do not use any mediators for electron transfer [Logan, 2004]. MFC devices convert the chemical energy into electrical energy by the process of oxidation of carbon and other organic matters [Rosenbaum et al., 2010] with the help of EABs [Angenent et al., 2004; Logan, 2009]. In MFCs, the major microbial population includes Geobacter [Lovely et al., 1993; Nevin et al., 2008] and Shewanella [Gorby et al., 2006; Watson and Logan, 2010]. Photosynthetic bacteria can also be efficiently used in the operation of MFCs. Cyanobacteria such as Anabaena and Nostoc can also be used as biocatalysts in MFCs [Tanaka et al., 1985]. Mixed cultures of microbial population, for example, a natural microbial community such as domestic and industrial wastewater, sediments from marine, lake and pond as well as anaerobic sludge were also used in MFCs [Logan, 2005; Rabaey et al., 2005; Feng et al., 2008]. The synergistic relationship works on the symbiotic functioning between photosynthetic bacteria (synthesize the organic matter by photosynthesis) and heterotrophic bacteria (utilize organic matter synthesized due to photosynthesis) were also used in MFCs for electricity generation [Tharali et al., 2016]. Most of the MFC studies are carried out at room temperature and only very few exoelectrogens are studied under thermo/ hyperthermophilic condition. Such as Ferroglobus placidus, Geoglobus ahangau and Pyrococcus furiosus exhibited electroactive behavior under extreme conditions [Sekar et al., 2017; Yelmazel et al., 2018]. Recently, halophilic bacterium such as Bacillus circulans BBL03 isolated from sea salt harvesting area was reported to exhibited high electricity production capacity as high as $26.51 \mu \mathrm{A} \mathrm{cm}{ }^{2}$ from the $1 \%$ of chitin biomass [Gurav et al., 2019]. MFC technology also has the wide application in bioremediation of toxic waste and biohydrogen generation as a clean source of energy in transportation and power generation sectors. As per the literature review more than
120 different species of microorganisms are identified as electrochemically active and used for the various applications in MFC technology. This review tried to provide an outline about the various exoelectrogens and its combination used in various MFCs to explore in various researches and industrial objectives.

\section{Exoelectrogens in MFCs}

In MFCs, microorganisms play a vital role in determining the power generation since it act as biocatalyst for the degradation of organic compounds. Electrochemically Active Bacteria (EAB) are the most suitable for the operation of MFCs as they have the ability for Extracellular Electron Transfer (EET) from the interior of the bacterial cell to the anode [Ortega et al., 2013]. Geobactor sulfurreducens is the most commonly identified exoelectrogen for MFCs application [Holmes et al., 2004; Lovley, 2006; Kiely et al., 2011]. It is reported that Geobacter spp. produces and transfers electrons directly to the anode through highly conductive pili. Shewanella oneidensis is another model exoelectrogens [Ringeisen et al., 2006; Bretschger et al., 2007; Rosenbaum et al., 2009; Watson and Logan, 2010; Liu et al., 2017; Liu et al., 2018]. Most other exoelectrogens make direct physical contact with the anode or mediate electron transfer through electron shuttles (mediators), which typically do not reach sufficient concentrations to maintain high current densities. Either a pure type or a mixed type culture was usually are typically used for the MFCs operation [Malvankar et al., 2012]. But most of the studies revealed that mixed bacterial culture is more efficient than pure bacterial culture. This is because, when bacteria exist in mixed colonies, electron transfer generally occurs synergistically. Scientists also shared the general impression that EAB is benefitted by the presence of non - conducting bacteria by means of quorum sensing. Sometimes mixed culture in MFC may decrease the current generation due to the presence of dominant methanogenic bacteria such as anaerobic sludge. MFC experiments using a pure culture of bacteria have revealed that many microorganisms, from firmicutes and actinobacteria phyla and all classes of proteobacteria, archaea are reported to be exoelectrogenic [Koch and Harnisch, 2016; Liu et al., 2018]. Some marine isolates 
such as Pseudomonas mendocina NR 802, $P$. pseudoalcaligenes and Bacillus circulans are also used for the low voltage power generation [Kumari et al., 2015; Gurav et al., 2019]. Temperature is one of the influencing factors on performance of MFCs. Most of the experiments in MFCs are carried out at room temperature, which is considered as the ambient temperature for the microbial growth. In contrast, Tkach et al. have reported about the electroactivity of pure culture of Enterobacter spp. ALL - 3 at $10^{\circ} \mathrm{C}$ [Tkach et al., 2015]. In addition, some hyperthermophilic archaeon such as Ferroglobus placidus, Geoglobus ahangau and Pyrococcus furiosus are reported to be electrochemically active without any mediators under extreme environmental condition [Yelmazel et al., 2018; Sekar et al., 2017]. Liu et al. have reported about the synergistic relationship between two microorganisms for efficient current generation in MFC system. They synthetically prepared binary culture of Bacillus subtilis RH33 and S. oneidensis MR1 and achieved a sustained power density of $277.4 \mathrm{~mW} \mathrm{~m}^{-2}$ for $500 \mathrm{hr}$. Here $\mathrm{RH} 33$ produce electron shuttle riboflavin and MR1 effectively utilize this riboflavin for efficient electron transfer. Thus both mediated and direct electron transfer is enhanced [Liu et al., 2017]. Cell - to - cell communication between the interspecies is another main method adopted by the microorganism for the exchange of nutrient and route for trafficking constituents. Dubey et al. and Pande et al. have reported about such cell - to - cell communication between E.coli and Actinobacter baylyi through a network of nanotubes. Thus can enhance the MFC performance by the exchanging the nutrients and electrons between the species that are distantly located from the electrode [Dubey et al., 2016; Pande et al., 2015]. Moreover, other than bacterial isolates, yeast - Pichia stipites are also reported to have the ability to transfer electron to the external anode through electron shuttle - flavin [Wu et al., 2014]. In addition to electricity generation, application of microbes in waste treatment and bioremediation makes MFC a promising technology in various sectors for waste management. Based on the availability of the biomass/waste, microbes used of its treatment also vary. For example, acidophilic microorganism was identified as effective in current generation by degrading inorganic sulfur compounds [Ni et al.,
2016]. Toxics such as vanadium (V) and chromium (VI) were degraded and removed using microbial metabolism of Shewanella iochica PV - 4 along with current generation [Wang et al., 2017]. Islam et al. have reported that Klebsiella varricola can effectively utilize palm oil effluent than anaerobic sludge and produced a power density of $1.7 \mathrm{~W} \mathrm{~m}^{-3}$ [Islam et al., 2017b]. Holkar et al. reported for the first time potential of Klebsiella spp C to remove anthraquinone based dye from textile waste and produced a current density of $533 \mathrm{~mA} \mathrm{~m}^{-2}$ [Holkar et al., 2018]. These open up new possibilities to bioremediate toxic waste using MFC technology. In addition to bioelectricity, production of biohydrogen from MFCs is also attracting much attention due to its wide application as clean energy source in various sectors. Various biomass are used for biohydrogen production, among which lignocellulosic biomass is now reported to be efficient for the biohydrogen production using dark fermentation [Kumar et al., 2018]. However comprehensive knowledge on exoelectrogens and its specific properties of electron transfer is essential to enhance the extracellular electron transfer. While considering all these literatures, it is clear that almost all types of bacteria namely gram positive and gram negative bacteria are prominently can act as exoelectrogens in most of the MFC applications. While comparing with gram-negative bacteria, relative less number of gram-positive bacteria is effectively applied for MFC application. It includes Clostridium butyricum, Clostridium beijerinckii, Bacillus subtilis, Saccharomyces cerevisiae, Paenibacillus lautus, and Bacillus thuringiensis. Most of the reported gram-positive bacteria are either belongs to facultative or obligate anaerobic. Some other potential bacteria used for the MFCs applications are enlisted in Table 1. All these details will help to the researchers to explore these exoelectrogens to improve the bioelectricity production and simultaneously for the waste treatment using MFCs in future.

\section{Electron transfer mechanism in MFCs Cytochromes}

Microorganisms use many electron transfer mechanisms in MFCs. Fig. 1 shows the different methods of electron transfer in MFCs. One of the electron transfer mechanisms of microorganisms is through cytochrome. Such 


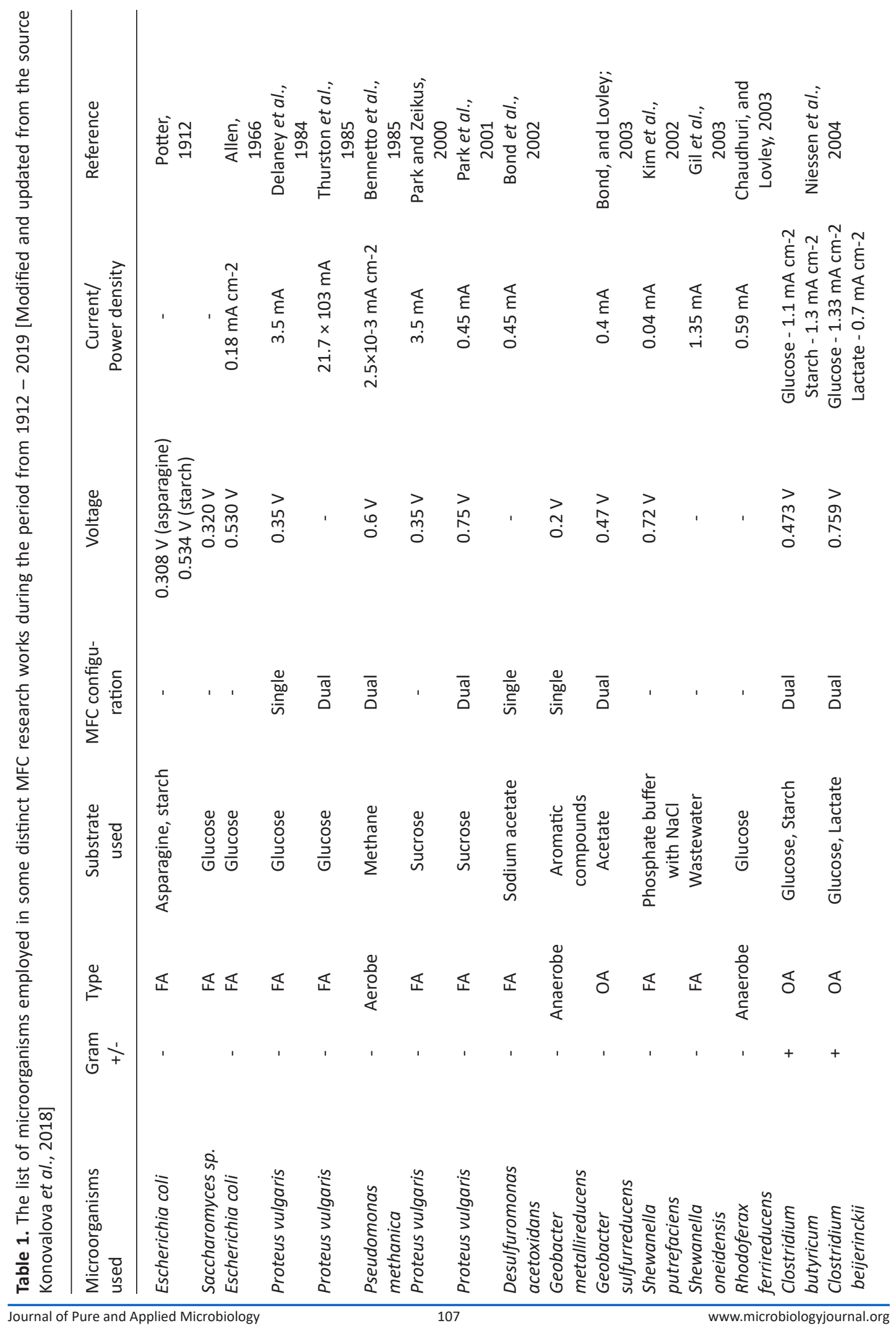




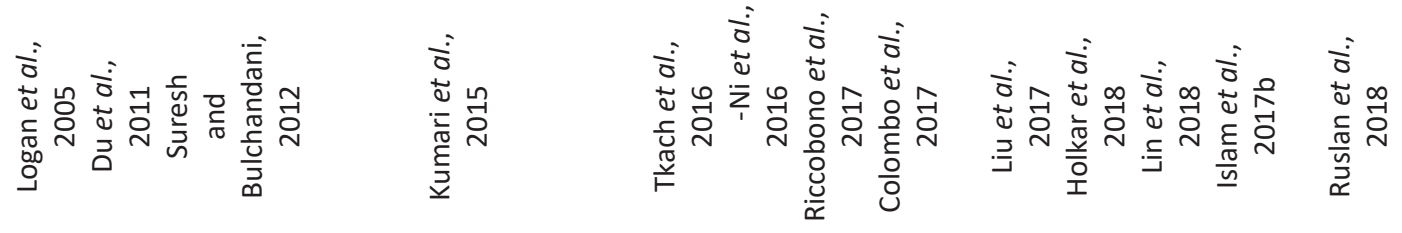



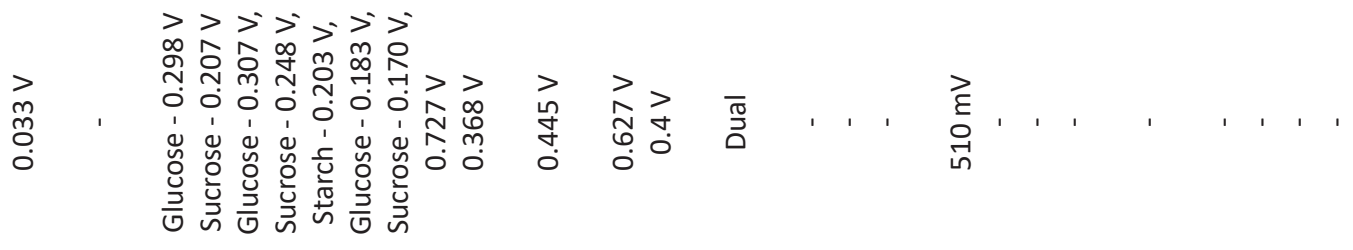

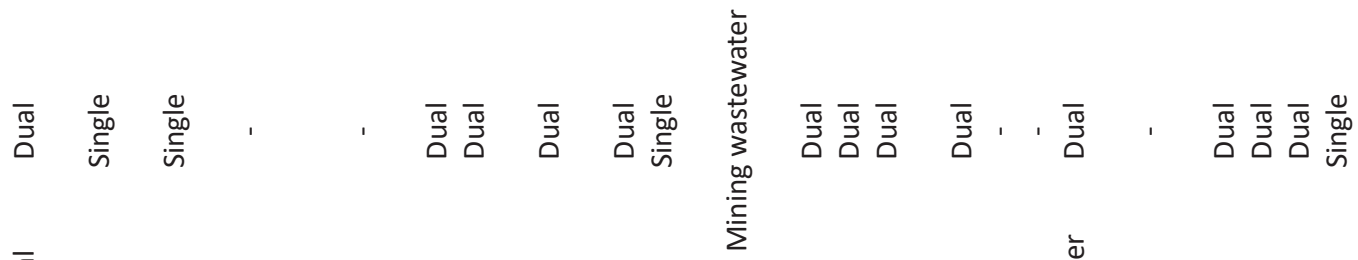

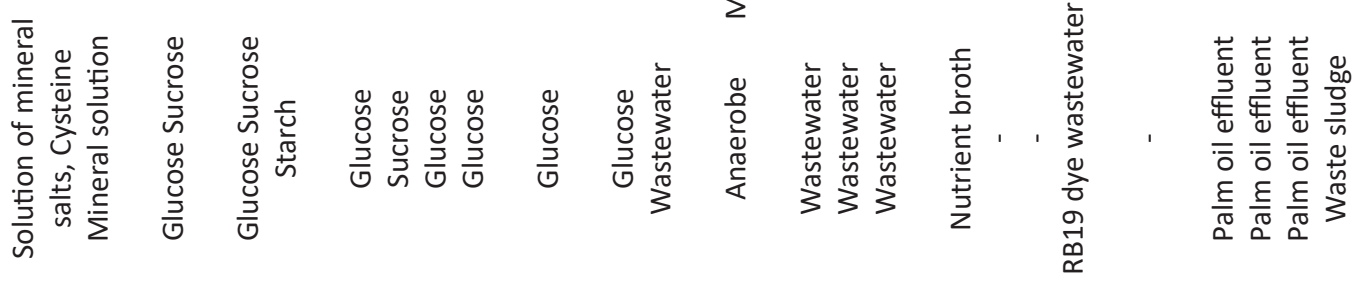

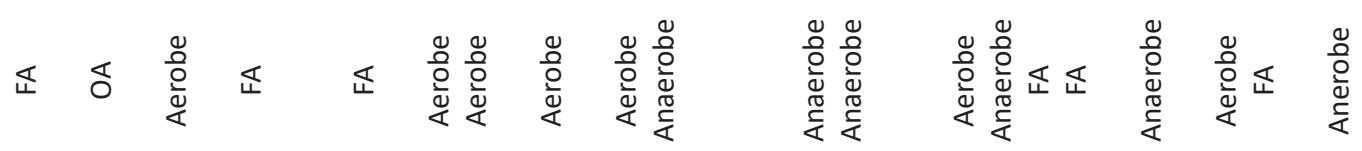

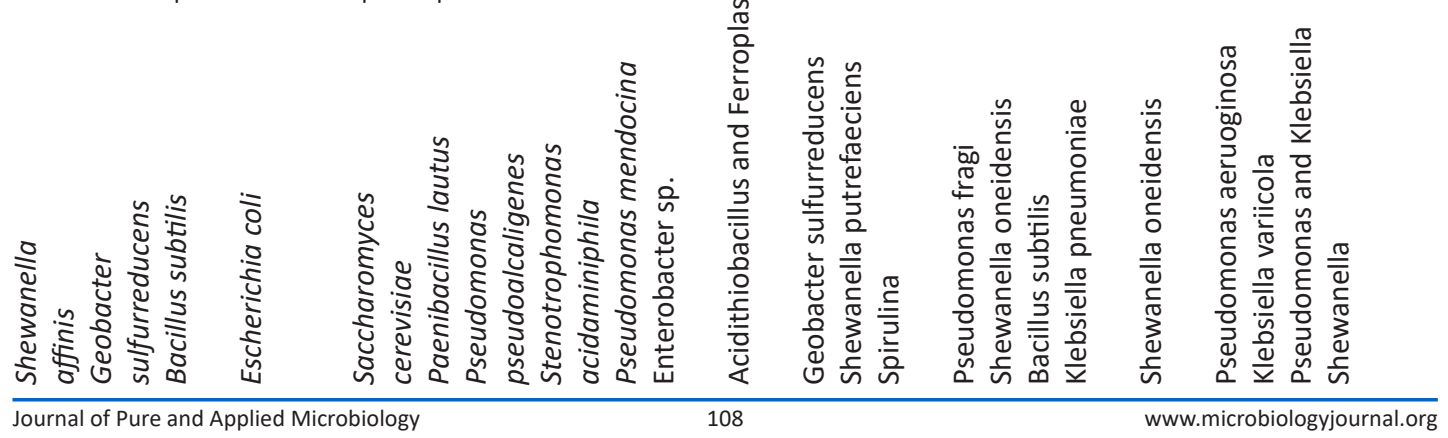




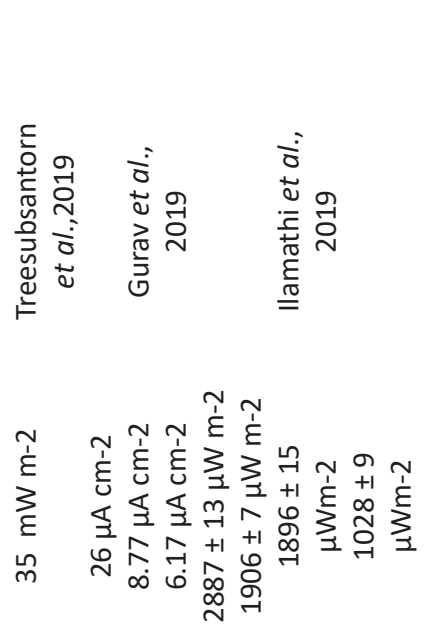

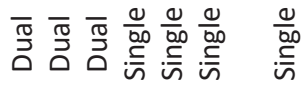



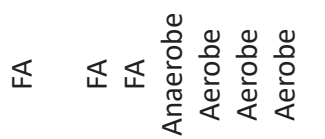


舟 organisms have the ability to oxidize various substrates and produce carbon dioxide by using citric acid cycle. Electrons generated during this process are transferred to Fe (III), presumably through menaquione and cytochromes that can be detected in the cell [Gorby et al., 1991]. Another type of microorganism, such as Geobacter, Shewanella and Rhodoferax, which are inhabitant of metal reducing sediment uses multi heme proteins i.e., C - type cytochromes [Breuer et al., 2014; Ruslan and Vadivedu, 2018; Aiyer, 2020]. The multi heme cytochromes in such microorganism contribute higher power density and other advances in the field of bioelectricity generation. The process of Direct Electron Transfer (DET) through outer membrane cytochromes requires a physical contact between the cytochromes on the bacterial cell and the fuel cell anode [Schroder, 2007]. Heme group in the cytochromes has a metal ion that is surrounded by a porphyrin ring and acts as an active site for redox reactions. The position of heme group differs according to different cytochrome but they are always located in deep pore inside the protein that is usually surrounded by non - polar amino acids. If the orientation of cytochrome on the surface of the electrode is unfavorable, then it will not allow the direct transfer of electrons between the electrode and active center [Qiao et al., 2010]. Microorganisms such as Geobacter sulfurreducens excrete flavin that are seen bound to the cytochrome [Okamoto et al., 2014]. In the outer membrane, the cytochrome are arranged in a particular pattern with the heme located in the opposites shorter and longer cross beam ends [Hong and Pachter, 2016].

Shewanella oneidensis uses cytochromes for the facilitation of electron transfer. These organisms have a network of $\mathrm{C}$ - type cytochromes which help in facilitated electron transfer from quionone in the inner membrane. Here the cytochrome $\mathrm{C}$ molecules are localized on the surface of bacterial cell which transfer electron to $\mathrm{Cr}(\mathrm{V})$ or $\mathrm{Cr}(\mathrm{VI})$ through direct or indirect transportation [Belchik et al., 2011]. Shewanella lohica was found to have more cytochrome C genes when compared to $S$. oneidensis in the metal reductase containing locus [Wang et al., 2017]. More detailed studies into the EET of this 
bacterium might throw more light into cytochrome - based transfer mechanisms.

\section{Pili or nanowires}

Pili are non flagellar hair like appendages made up of polypeptide that are present in bacterial cells. They are seen in many secretion pathways. These are mostly associated with the outer membrane cytochrome in most of the exoelectrogens causes the direct electron transfer [Malvankar et al., 2012; Kumar et al., 2018]. They are also involved in several cellular functions such as attachment of cells to the substrate, cell-cell signaling, and transfer of genetic materials from one another (conjugation) and biofilm formation [Kline et al., 2010]. A class of appendages, pilin like structures which are termed as nanowires found in bacteria. Proteins such as prepilin peptidases are found in bacteria required for the expression of pili through pilin secretion pathway [Gorby et al., 2006]. In Pesudomonas aeroginosa, the transfer of electrons can occur through pili [Reguera et al., 2005]. In some strains where there are no direct contacts between cells, pili can extend its appendages to allow the shuttling of electrons out of the cells by synthesizing their soluble mediators such as phenazine, riboflavin etc. [Rabaey et al., 2004; Qiao et al., 2008]. In Geobacter species, pili are involved in the reduction of Fe (III). Gene namely $P$ il $A$, that encode for a pilin protein are expressed in higher level when Geobacter is grown in Fe (III) oxide. This indicates that this gene is required for the insoluble Fe (III) oxide reduction [Childers et al., 2002]. In case of Shewanella japonica, pili play a key role in formation of biofilm and are expected to form a thick biofilm [Thormann et al., 2004].

\section{Extracellular mediators}

The external mediators are used in case of MFCs using a single population model where there is dependence between power output and external mediators [Bond et al., 2002]. In the absence of exogenous mediators, organisms such as Shewanella and Geobacter can transfer electron through extracellular electrons acceptors [Kim et al., 1999; Bond et al., 2002].

In Shewanella japonica, the metabolic pathways are coupled to extracellular electron transfer processes for the utilization of different carbon sources such as glucose, sucrose, and fructose for the generation of electricity. Organisms such as S. oneidensis and Shewanella japonica synthesises soluble mediators that can mediate electron transfer [Biffinger et al., 2011]. The Geobacteriaceae can use insoluble extracellular electron acceptors to transfer the electrons outside the cell to Mn (IV) and Fe (III) oxides and thus provide electricity [Lovley, 2017]. However, the greatest disadvantage of mediator molecules is that, they work by the principle of diffusion, which is a relatively slow process. Moreover,

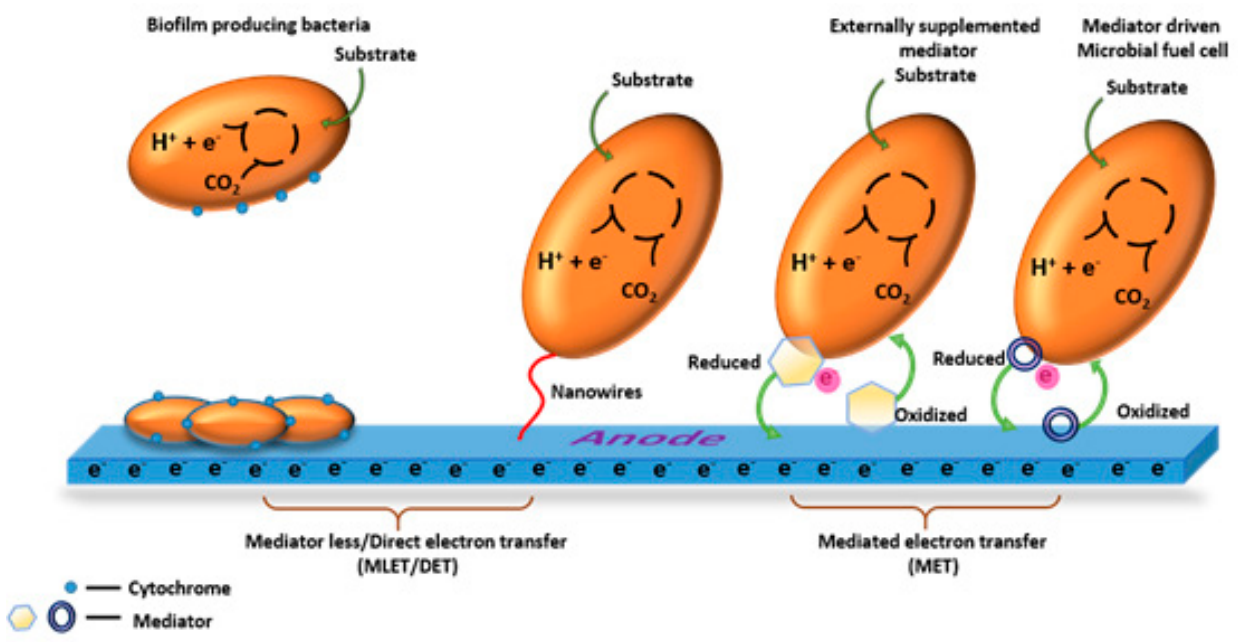

Fig. 1. Illustration of different methods of electron transfer in MFCs, mediator -less/direct electron transfer (DET) and mediated electron transfer (MET) [Source: Rabaey et al., 2004; Rabaey et al., 2005; Rabaey et al., 2007; Schroder, 2007; Logan, 2009] 
electron transport via mediators follows indirect mechanism of transfer of electrons [Lovley, 2017]. MFC with some non exoelectrogens make of external mediators for the efficient electron transfer. But most of the mediators used are highly toxic and expensive. Thus the exploration of such external mediators is not encouraged for the MFC application. Therefore the use of naturally produced electron mediators is mainly used by some non exoelectrogens for the efficient electron transfer in MFC. Such as Yeast, which do not have the capability to produce mediators, can utilize the electron mediators secreted by Bacillus. Spp WS - XY1 and Klebsiella pneumonia and enhanced the performance in MFC through synergistic interaction [Islam et al., 2017a; Wu et al., 2014]. cable bacteria

Some bacteria seem to mediate long range interspecies electron transport from anaerobic region to aerobic regions. This is facilitated by forming long chains comprising of cells in which each cell is stacked upon the other. This is most commonly seen in Desulfobulbacaea and is involved in oxidation of sulphide minerals in anoxic environments [Pfeffer et al., 2012; Lovley, 2017]. It is proposed that cable bacteria carry the electrons during this oxidation process through this chain of cells to the oxic zone where it is transferred to the external oxygen. The electrons are carried through highly electro - conductive ridges that run along the central region of all the member cells. However, this mode of electron transfer is detected to be confined within the cells and is not transmitted to the external environment. It is expected that detailed studies of their ecology and mode of transfer of electrons would be valuable in utilizing this technique in MFCs.

\section{Conductive biofilms}

Biofilm plays a key role in MFCs, since the formation of biofilm on the anode oxidizes the organic compounds and thus helps in the transfer of electrons to the anode. Earlier studies showed that most biofilms are electronically insulators, but biofilms generated by Geobacter sulfurreducens shows some electronic conductivity. The extracellular electron transfer through a conductive biofilm is found to be an effective mechanism for high power density [Malvankar et al., 2012]. G. sulfurreducens is able to produce high current densities due to their ability to produce conductive biofilms [Malvankar et al., 2011]. Studies show that higher amount of biofilm with conductive nature can enhance the performance of the density of fuel cell. These biofilms provide lower resistance to the electron flow in MFCs and also it lowers the activation energy barrier required for the transfer of electron between the anode and the biofilm [Malvankar et al., 2012]. Highly structured microbial communities are seen attached to the electrodes that can form electrochemically active biofilms [Logan and Rabaey, 2012].

A 3D hybrid using reduced graphene oxide is constructed to produce biofilm in $S$. oneidensis MR1. These GO can act as macroporous network which would enhance the incorporation of a large amount of bacteria into biofilm matrix and can be utilized for multi complexed conductive pathways, thereby enhancing EET between bacteria and electrode. Thus, the performance of the MFCs can be enhanced [Yong et al., 2014]. In some bacteria, conduction of electrons to the anode was takes place through the membrane bound conductive materials in the biofilm matrix. [Laspidou and Rittmann, 2004]. In a study conducted using Geobacter sulfurreducens, pure culture of $G$. sulfurreducens can produce high power density than mixed species of biofilms [Ishii et al., 2008; Nevin et al., 2010]. They form thick biofilm that is metabolically active and produce a high current density [Reguera et al., 2006; Nevin et al., 2008]. Microbial biofilm can act as biocatalyst by oxidizing complex organic matter to produce electric current [Rabaey and Rozendal, 2010]. A hybrid based on the graphene carbon nanotube is built in the anode to act as a network for bacteria in MFCs. This network allows the biofilm to attach into the carbon surface firmly. The graphene provides high mechanical flexibility and surface area facilitating high extracellular electron transfer between microbial biofilm and the electrode. This offers a large amount of area for bacterial growth to occur, thus enhancing the power density of the MFCs and a maximum power density of $97.9 \mu \mathrm{W} \mathrm{cm} \mathrm{cm}^{-2}$ was recorded [Zhao et al., 2015]. All these studies evident the facts that, biofilm forming exoelectrogens are more suitable 
for the bioelectricity generation compared to others. Since it can form a stable and comfort film on the surface of the anode and can transfer and mediate the electrons directly to the anode without any loss.

Different mechanisms of Extracellular Electron Transfer (EET)

EET by Gram-negative microorganisms

Most of the electrochemically active bacteria are Gram-negative in nature. This is because of the characteristic location of $\mathrm{C}$ - type cytochromes and other electrochemically active moieties and structures along the exterior end of outer membrane. Mostly, electron transfer in Gram - negative bacteria takes place through direct transfer mechanisms as discussed earlier. Most prominent electricigens reported so far Geobacter species and Shewanella species are Gram - negative. Other famous Gram - negative bacteria include E. coli and Pseudomonas species. Various mechanism of electron transfer system are existing in nature, among which the two most prominent predicted models for electron transfer mechanism were OMC system in Geobacter species and Mtr pathway in Shewanella species. Geobacter sulfurreducens shows the EET through direct electron transfer by thick biofilm formation [Reguera et al., 2006]. The presence of cytochrome can achieve the transport of electrons through the multilayer biofilm to the anode. Fig. 2A illustrates the EET pathway by Geobacter sulfurreducens through outer membrane cytochrome (Omc) complex. In this system, metal reduction associated cytochrome (Mac A) acts as a transmitter for the transfer of intracellular electrons to periplasmic C type cytochrome (Ppc A), followed by the transfer of electrons to the Omc complexes (Omc Z) on the outer membrane and then to the extracellular electron acceptor. Another method was through the nano - wires or pili, which can enable physical contact with the bacterial cell and surface of the anode [Reguera et al., 2006]. One proposed model of electron transfer was based on the electron delocalization through $\Pi$ - stacking of aromatic amino acid residue in the pili [Malvankar et al., 2011; Malvankar et al., 2015]. Another is based
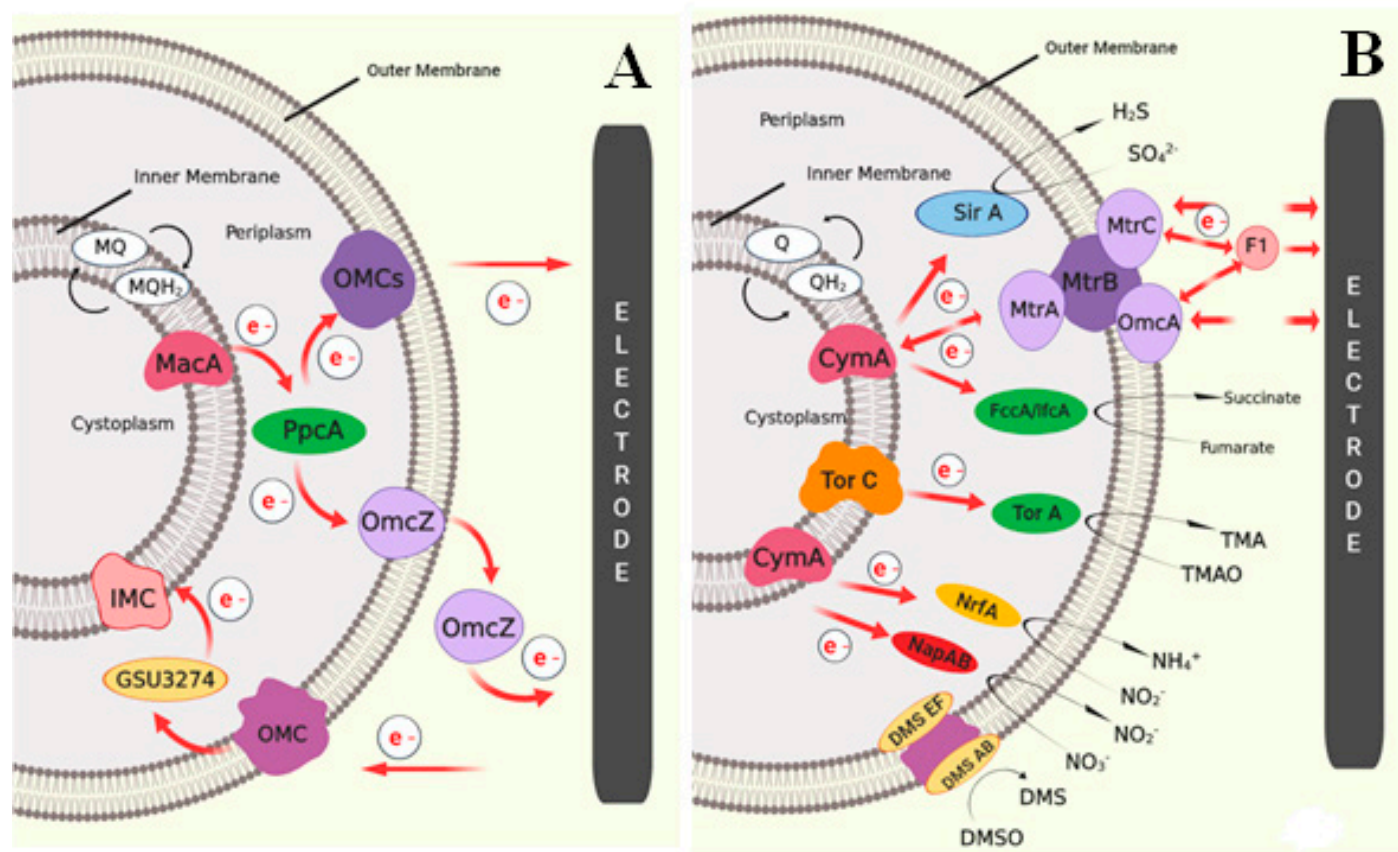

Fig. 2. Schematic image of proposed EET of two metal reducing Gram - negative bacteria in MFCs: (A) EET pathway shown by $G$. sulfurreducens through outer membrane cytochrome $(\mathrm{Omc})$ complex, and (B) EET pathway shown by $S$. oneidensis, where electrons are transferred from quinines to CymA or TorC complex then get transferred to MtrABC complex [Sources: Kracke et al., 2015; Kumar et al., 2018] 
on the hopping of electrons along the redox active protein to the final electron acceptor [Malvankar et al., 2012]. Another proposed model of EET transfer was based on the Mtr pathway in $S$. oneidensis. The proposed EET pathway adopted by Shewanella oneidensis are shown in Fig. 2B.

Here the oxidation of electron carriers like quinols catalysed by the tetraheme cytochromes such as TorC and CymA. Thus, generate a proton gradient for the energy conversion in the form of ATP. TorC and CymA interact with different redox partners in the periplasm and outer membrane molecules as the electron acceptors. Like TorA in the periplasm utilizes trimethylamine $\mathrm{N}$ - oxide compound [Dos Santos et al., 1998], sulphite can be reduced by SirA [Shirodkar et al., 2011], nitrite by NrfA [Gao et al., 2009], nitrate by NapAB [Simpson et al., 2010] and fumarate by FccA and IfcA reductase molecules [Maier et al., 2003]. In addition, S. oneidensis can also utilize extracellular insoluble metal as electron acceptor such as electrodes. This method was suggested as the most widely explored method for EET. Here, decaheme cytochrome (MtrA) can take up electrons from the CymA and transfer to the extracellular MtrC, which transfer the electron finally to the extracellular acceptor. MtrA, MtrC and MtrB form a complex on the outer membrane and MtrB helps to organize and stabilize the MtrA and MtrC together. White et al. also detected the presence of OmcA molecule anchored to the Mtr complex, which can also transfer the electrons to the exogenous electrode [Myers and Myers, 2000; Coursolle and Gralnick, 2010; Shi et al., 2012; White et al., 2013; Breuer et al., 2015]. In addition to direct electron transfer by biofilm formation, S. oneidensis can also transfer electrons indirectly using secretion of flavin molecules [Marsili et al., 2008; Okamoto et al., 2013]. It is reported that, genetic engineering effort on EET pathways and metabolism of a membraneassociated CymA, can further increased the electrochemical performance of the MFCs by enforcing overexpression of CymA in S. oneidensis [Vellingiri et al., 2019]. Based on this, Liu et al. tried to design S. oneidensis to enhance flavin - biofilm hybrid through synthetic biological approach to enhance both direct and mediated electron transfer. For that, ptet promoter was constructed for the expression of flavin biosynthesis gene (rib ADEHC). This enable enhanced flavin synthesis in S. oneidensis. Hydrophobic entities in the cell membrane inhibit its transport; thus porin gene
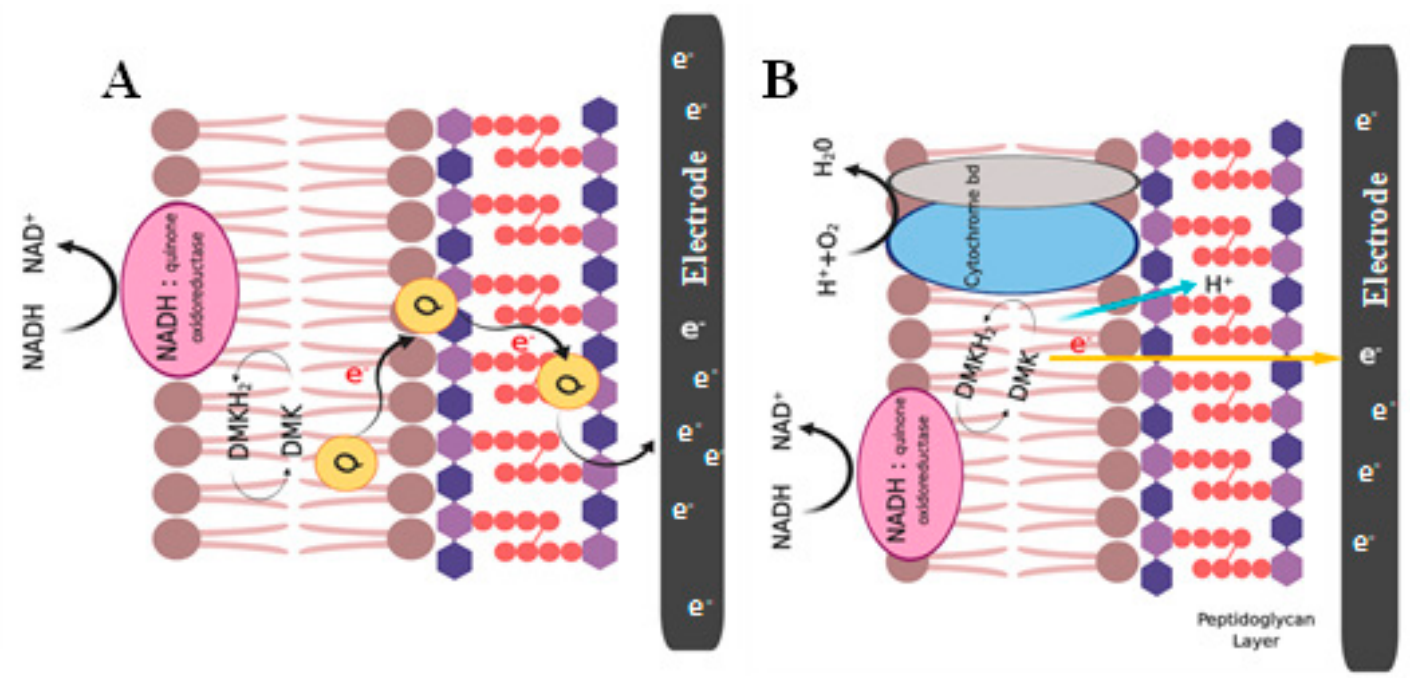

Fig. 3. Schematic representation of EET mechanism of Gram-positive bacteria Enterococcus faecalis via (A) NADH oxidoreductase, quinine act as a self - generated mediators which transport electrons through outer thicker peptidoglycan layer to the electrode where cytochrome bd oxidase enzyme was not involved; (B) EET pathway through the presence of cytochrome bd in the lipid bilayer without the use of endogenous mediators [Sources: Pankratova et al., 2018] 
(Opr F) originated in P. aeruginosa was incorporate into $S$. oneidensis for the efficient transport of synthesized flavin across the cell membrane and thus enhanced the overall electron transfer and thereby the performance of MFC [Liu et al., 2018]. Other microorganisms like $M$. thermoacatica can transfer electron through cytochrome or Ech complex, but no experimental data supports this hypothesis. Recently, Wood - Ljungdahl pathway proposed by Nelvin et al. in A. woodii provided breakthrough in the field of bioelectrochemical techniques [Nevin et al., 2010]. A. woodii belongs to the $\mathrm{Na}^{+}$dependent acetogens, which lack cytochromes. Wood - Ljungdahl pathway in $A$. woodii was coupled with the generation of $\mathrm{Na}$ gradient across the membrane. Later, Muller et al. evidenced the presence of novel membrane bound Rnf complex, which was responsible for $\mathrm{Na}^{+}$transport [Muller et al., 2008]. The $\mathrm{F}_{1} \mathrm{~F}_{0}$ ATP synthase also harvested the $\mathrm{Na}$ gradient. This gradient results in generation of electron conversion and transfer of an electron to the outer electron acceptor [Biegel et al., 2011]. Such Rnf complex pathway of electron transfer is also detected in C. ljungdahl [Kopke et al., 2010; Schuchmann and Muller, 2014].

\section{EET by Gram - positive microorganisms}

In contrast, Gram - positive bacteria are preferably non - electrogenic as they are covered by thick cell envelope which comprises of insulating peptidoglycan, lipopolysaccharides and lipid bilayers [Pankratova et al., 2019]. These compounds mask most of the electroactive membrane structures such as cytochromes from interacting with the external environment. This may be one reason why they are poor performers when it comes to exchange of electrons with the external environment. However, there are a few electrochemically active species reported so far, such as Bacillus spp., Lactococcus lactis, Enterococcus faecalis [Wu et al., 2014; Pankratova et al., 2019], Eubacterium, Clostridium butyricum [Park et al., 2001] and Lactobacillus rhamnosus [Yamazaki et al., 2002]. The schematic representation of proposed EET mechanism of Gram-positive bacteria Enterococcus faecalis are shown in Fig. 3(A and B). Pankratova et al. studied the mechanism in $E$. faecalis by external supplemented with heme. Thus two heme proteins such as catalase and cytochrome bd are assembled [Winstedt et al., 2000; Frankenberg et al., 2002]. Reduction of demethylmenaquinone (DMK) takes place at the periplasmic space by various membrane associated dehydrogenases such as $\mathrm{NADH}$ : quinone oxidoreductase. This can generate proton gradient across the membrane. The presence of quinine acts as self-generated mediators which transport electrons through outer thicker peptidoglycan layer to the extracellular electrode in the absence of cytochrome. The presence of cytochrome bd in the lipid bilayer was composed of two protein subunits, CydA and $\mathrm{CydB}$, and three heme prosthetic groups [Borisov et al., 2011; Safarian et al., 2016]. In the case of E. faecalis, glycolysis and pyruvate dehydrogenase activity yields 4 mol of NADH per mole of glucose, potentially providing eight electrons and can be transferred to an extracellular electrode.

As the electroactive moieties are masked from the external environment, the main mode of electron transfer in Gram-positive bacteria is proposed to be via. soluble mediators secreted by the cells. Numerous studies proposed that these bacteria were capable of producing diffusible mediators for enabling mineral reduction. The advantage of such mediators in Electron Transfer (ET) is that they can carry electrons embedded deep inside the cells or the inner layers of biofilm to the anode surface. L. lactis produce quinones, the electrochemical properties of which have been established [Pankratova et al., 2019]. ET in Bacillus is mediated chiefly by flavin molecules [Nimje et al., 2009; Wu et al., 2014]. These are the electrochemically active mediators reported in Shewanella spp. too. In Bacillus, Flavin molecules are proposed to act by two methods: (1) by enhancing Mediated Electron Transfer (MET) in other membranes (2) by inhibiting the growth of methanogens when grown in consortia [Islam et al., 2017a]. Further, recent study revealed the presence of electrochemically active EPS in Bacillus spp. [Xiao et al., 2017]. The presence of these polymers makes the biofilm of the Bacillus spp. electrochemically active, which is an added advantage to the performance of MFCs with Bacillus as the chief electrogenic species.

Exploration of extremophiles such as Ferroglobus placedus, Geoglobus Ahangau and Pyrococcus furiosus in MFC broaden the possibility of application of such technologies 
for energy production in extreme conditions. All these are hyperthermophilic in nature and reported to produce the current at $90{ }^{\circ} \mathrm{C}$ without any external mediators. Another advantage of these extremophiles is that they can metabolize wide range of carbohydrates [Sekar et al., 2017; Yelmazel et al., 2018]. Pyrococcus furiosus uses simple respiratory electron transport chain via of membrane bound hydrogenase (MBH). This bacterium contains trehalose/maltose binding protein (TMBP) for the efficient transport of maltose into the cell. Where, it is hydrolyzed to glucose and enters the glycolytic pathway. In the case of hyperthermophiles, rather than $\mathrm{NADH}$, ferridoxin connects the carbon metabolism and respiratory chain [ Sapra et al., 2003; Sekar et al., 2017]. More studies in the area of EET transport mechanism in such extremophiles open up a new technology to operate under extreme conditions. Apart from bacteria, EET is also reported in other groups such as archeae and eukarya. Obligate anaerobes such as hyperthermophilic archeae and methanogenic archeae possess electrogenic properties in lesser magnitudes when compared to that of bacteria. Archaeal species with reported activity are $P$. furiosus $(225 \mathrm{~mW}$ $\left.\mathrm{m}^{-2}\right)$ [Sekar et al., 2017], F. placidus $\left(680 \mathrm{~mA} \mathrm{~m}^{-2}\right)$ and Geoglobus ahangari (570 $\mathrm{mA} \mathrm{m}^{-2}$ ) [Yilmazel et al., 2016]. Among eukaryotes, members of Saccharomycetaceae are known to generate electricity. Yeast based MFCs made a power of the magnitude of $20-70 \mathrm{~mW} \mathrm{~m}^{-2}$ [Hubenova and Mitov, 2015a] and that with Candida spp. IR11 made a power of $\sim 21 \mathrm{~mW} \mathrm{~m}^{-2}$ [Hubenova and Mitov, 2015b]. Several studies report better performance by the yeast cells and other fungi when the media are either optimized [Hubenova et al., 2010], or the cells were immobilized on anode surface [Hubenova and Mitov, 2015a]. Biomass availability also determines its pathway of electron transfer. For example, halophilic bacterium namely Bacillus circulans BBL03 generated a current density of $26.508 \mu \mathrm{A} \mathrm{cm}^{-2}$ utilizing chitin as biomass [ Gurav et al., 2019] Chitin is hydrolysed by the secretion of chitinase results in the production of metabolites such as lactate, formate, acetate, etc. These metabolites further acts as electron donor. It was also reported that, Echinodosus cordifolus plant can support and maintain the growth of Bacillus thuringiensis in MFC system and results in generation of sustained power desnty of 20-35 $\mathrm{mW} \mathrm{m}^{-2}$ for more than 180 days [ Treesibsuntorn et al., 2019].

\section{Ecology of exoelectrogenic microorganism}

In nature, electron transport/exchange between distinct species or to the external electron acceptors is a tedious process that helps bacterial cells to survive. The exoelectrogenic bacteria establish connections either with the external environment or with other electrotrophic species in its microenvironment which enable them to explore nutrients and the environment which are otherwise inaccessible to them. Thus, many genetically and metabolically distinct bacteria are seen to establish different types of connections among them. It is pretty fascinating that most of these connections are mediated by electron shuttle/exchange because a deep understanding of such mechanisms will be of great help in developing better modes of electron tapping in MFCs.

Direct interspecies electron transfer mechanism Direct Interspecies Electron Transfer (DIET) is a tool by which many bacterial species living as consortia in some anaerobic environments establish connections with each other for the benefit of either of them. They do so by means of conductive pili, cytochromes, minerals and abiotic carbon [Lovley, 2017]. Other structures such as nanotubes are also involved in similar mechanisms [Pande et al., 2015; Dubey et al., 2016; Lovley, 2017]. A number of electrochemically active bacterial species possess long conductive pili generally known as e - pili. These structures are used to establish connections with far - off cells in the environment. Electron transports through these connections take place either by means of C -type cytochromes embedded along their inner regions [Malvankar et al., 2012] or through membrane vesicles [Hasegawa et al., 2015]. Electron shuttle through embedded structures are relatively faster when compared to other modes. Still, transport of electrons through the intercellular connections employing membrane vesicles and other soluble electron carriers are relatively faster than that by extracellular mediators, as the shuttle through the interiors of cells is more specific and targeted when compared to efflux of electrons into the external environment. As reported earlier, direct interspecies electron transfer is also 
mediated by nanotubular structure which extent from cytoplasm of one bacterial cell to another [ Dubet et al., 2016; Pande et al., 2015].

\section{Synergistic interactions}

At times, some bacterial species in co cultures are seen to establish trans - membrane connections through which they exchanged soluble molecules. Such connections seem to enhance the metabolic activities of the members. For example, such a relationship between the cells of Desulfovibrio vulgaris and Clostridium acetobutylicum empowered $D$. vulgaris to grow in sulphate free environments. This was made possible by the shuttle of ferrodoxin from $D$. vulgaris to $C$. acetobutylicum. The ferrodoxin is produced by $D$. vulgaris, reduced inside the cell during metabolism, and then transported via. DIET to the interiors of $C$. acetobutylicum cells, where it is oxidized. The oxidized ferrodoxin is then carried back to $D$. vulgaris, thus facilitating metabolic electron shuttle between two distinct species of bacteria [Benomar et al., 2015; Lovley, 2017]. Another example of synergistic interactions facilitated by cell - cell connections is the co - existence of $G$. sulfurreducens and G. metallireducens. G. metallireducens derive electrons from ethanol substrates converting them to acetate. G. sulfurreduces survive solely on the electrons and the acetate derived from DIET. These two species are connected through e - pili and therefore, it is not necessary that these two types of species remain in close proximity within the environment. This pattern of electron exchange was confirmed by microscopic examinations too, and the cells appeared as distinct clusters embedded in a grid of e - pili [Lovley, 2017; Summers et al., 2010]. Liu et al. have reported about the synergistic electron transfer between S. onediensis MR - 1 and B. subtilis RH33 and generated a sustained power density of 277.4 $\mathrm{mW} \mathrm{m} \mathrm{m}^{-2}$ for more than $500 \mathrm{hr}$ [Liu et al., 2017]. Pande et al. have reported about the interspecies communication between $A$. baylyi and E. coli via nanotubular straucture. This enables distribution of nutrient and metabolic function within the connected microbial communities. This connection may also help to transfer the electrons between the cells and finally to the anode.

Conclusions and future prospective Building an extensive literature review on various exoelectrogens is the foundation to uncover the ecology and complexity of MFC bacterial communities. Different electron transfer mechanisms exhibited by different organisms are detailed in the present review paper. Moreover, predicted mechanism exhibited by model organisms that belong to both grampositive and gram-negative are also described in the current manuscript. The exoelectrogenic bacteria establish connections either with the external environment or with other electrotrophic species in its microenvironment which enable them to explore nutrients and the environment which are otherwise inaccessible to them. A deep understanding into such mechanisms will be of great help in developing better modes of electron tapping in MFCs. Genetic engineering of such model organisms can boost EET rate. In the light of specific characters of microorganism required for MFC applications, in various industrial sectors, the ecological knowledge of microbial resources is essential for extending the foundation and future developments in MFC. Understanding of bioelectricity production by various exoelectrogens and its changes over time in the MFC opens up a new world to combat excess energy consumption.

\section{ACKNOWLEDGEMENTS}

The authors gratefully acknowledge the administrative and infra structural help received from Department of Biotechnology, University of Kerala, Karyavattom Campus, Thiruvananthapuram, India.

\section{FUNDING}

None.

\section{DATA AVAILABILITY}

All datasets generated or analyzed during this study are included in the manuscript and/or the Supplementary Files.

\section{ETHICS STATEMENT}

This article does not contain any studies with human participants or animals performed by any of the authors.

\section{REFERENCES}

1. Aiyer KS. How does electron transfer occur in microbial fuel cells?. World Journal of Microbiology 
and Biotechnology, 2020; 36(2): 19. https://doi. org/10.1007/s11274-020-2801-z

2. Alcayde A, G Montoya, F, Banos R, Perea-Moreno A J \& Manzano-Agugliaro F. Analysis of Research Topics and Scientific Collaborations in Renewable Energy Using Community Detection. Sustainability, 2018; 10(12): 4510. https://doi.org/10.3390/su10124510

3. Allen MJ. The electrochemical aspects of some biochemical systems - IX. The anomalous behaviour of $E$. coli with mixed substrates. Electrochimica Acta, 1966; 11(10): 1503-1508. https://doi. org/10.1016/0013-4686(66)80066-X

4. Angenent L T, Karim K, Al-Dahhan MH, Wrenn BA \& Domiguez-Espinosa R. Production of bioenergy and biochemicals from industrial and agricultural wastewater. TRENDS in Biotechnology, 2004; 22(9): 477485. https://doi.org/10.1016/j.tibtech.2004.07.001

5. Belchik SM, Kennedy DW, Dohnalkova AC, Wang $Y$, Sevinc PC, Wu H, Lin Y, Lu HP, Fredrickson JK \& Shi L. Extracellular reduction of hexavalent chromium by cytochromes MtrC and OmcA of Shewanella oneidensis MR - 1. Applied and Environmental Microbiology, 2011; 77(12): 4035-4041. https://doi. org/10.1128/AEM.02463-10

6. Bennetto HP, Delaney GM, Mason JR, Roller SD, Stirling JL \& Thurston CF. The sucrose fuel cell: efficient biomass conversion using a microbial catalyst. Biotechnology Letters, 1985; 7(10): 699-704. https://doi.org/10.1007/BF01032279

7. Benomar S, Ranava D, Cardenas ML, Trably E, Rafrafi Y, Ducret A, Hamelin J, Lojou E, Steyer JP \& GiudiciOrticoni MT. Nutritional stress induces exchange of cell material and energetic coupling between bacterial species. Nature communications, 2015; 6: 6283. https://doi.org/10.1038/ncomms7283

8. Biegel E, Schmidt S, Gonzalez JM \& Muller V. Biochemistry, evolution and physiological function of the Rnf complex, a novel ion - motive electron transport complex in prokaryotes. Cellular and Molecular Life Sciences, 2011; 68(4): 613-634. https:// doi.org/10.1007/s00018-010-0555-8

9. Biffinger JC, Fitzgerald LA, Ray R., Little BJ, Lizewski SE, Petersen ER, Ringeisen BR, Sanders WC, Sheehan PE, Pietron JJ \& Baldwin JW. The utility of Shewanella japonica for microbial fuel cells. Bioresource Technology, 2011; 102(1): 290-297. https://doi. org/10.1016/j.biortech.2010.06.078

10. Bond DR \& Lovley DR. Electricity production by Geobacter sulfurreducens attached to electrodes. Applied and Environmental Microbiology, 2003; 69(3): 1548-1555. https://doi.org/10.1128/ AEM.69.3.1548-1555.2003

11. Bond DR, Holmes DE, Tender LM \& Lovley DR. Electrode - reducing microorganisms that harvest energy from marine sediments. Science, 2002; 295(5554): 483-485. https://doi.org/10.1126/science.1066771

12. Borisov VB, Gennis RB, Hemp J \& Verkhovsky MI. The cytochrome bd respiratory oxygen reductases. Biochimica et Biophysica Acta (BBA) Bioenergetics, 2011; 1807(11): 1398-1413. https:// doi.org/10.1016/j.bbabio.2011.06.016

13. Bretschger O, Obraztsova A, Sturm CA, Chang IS,
Gorby YA, Reed SB, Culley DE, Reardon CL, Barua S, Romine MF, Zhou J, Beliaev AS, Bouhenni R, Saffarini D, Mansfeld F, Kim BH, Fredrickson JK \& Nealson KH Current production and metal oxide reduction by Shewanella oneidensis MR - 1 wild type and mutants. Applied and Environmental Microbiology, 2007; 73(21): 7003-7012. https://doi.org/10.1128/ AEM.01087-07

14. Breuer M, Rosso KM, Blumberger J \& Butt JN. Multi haem cytochromes in Shewanella oneidensis MR - 1: structures, functions and opportunities. Journal of The Royal Society Interface, 2015; 12(102): 20141117. https://doi.org/10.1098/rsif.2014.1117

15. Chaudhuri SK \& Lovley DR. Electricity generation by direct oxidation of glucose in mediatorless microbial fuel cells. Nature Biotechnology, 2003; 21: 1229-1232. https://doi.org/10.1038/nbt867

16. Childers SE, Ciufo S \& Lovley DR. Geobacter metallireducens accesses insoluble Fe (III) oxide by chemotaxis. Nature, 2002; 416(6882): 767. https:// doi.org/10.1038/nbt867

17. Colombo A, Marzorati S, Lucchini G, Cristiani P, Pant D \& Schievano A. Assisting cultivation of photosynthetic microorganisms by microbial fuel cells to enhance nutrients recovery from wastewater. Bioresource Technology, 2017; 237: 240-248. https://doi. org/10.1016/j.biortech.2017.03.038

18. Delaney GM, Bennetto HP, Mason JR, Roller SD, Stirling JL \& Thurston CF. Electron - transfer coupling in microbial fuel cells. 2. performance of fuel cells containing selected microorganism - mediator - substrate combinations. Journal of Chemical Technology and Biotechnology. Biotechnology, 1984; 34(1): 13-27. https://doi.org/10.1002/ jctb. 280340104

19. Dos Santos JP, lobbi-Nivol C, Couillault C, Giordano G \& Mejean V. Molecular analysis of the trimethylamine $\mathrm{N}$ - oxide (TMAO) reductase respiratory system from a Shewanella species. Journal of Molecular Biology, 1998; 284(2): 421-433. https://doi.org/10.1006/ jmbi.1998.2155

20. Du F, Xie B, Dong W, Jia B, Dong K \& Liu H. Continuous flowing membraneless microbial fuel cells with separated electrode chambers. Bioresource Technology, 2011; 102(19): 8914-8920. https://doi. org/10.1016/j.biortech.2011.07.056

21. Dubey GP, Mohan GBM, Dubrovsky A, Amen T, Tsipshtein S, Rouvinski A, Rosenberg A, Kaganovich D, Sherman E, Medalia O, Ben-Yehuda S \& Ben-Yehuda S. Architecture and characteristics of bacterial nanotubes. Developmental Cell, 2016; 36(4): 453-461. https://doi.org/10.1016/j.devcel.2016.01.013

22. Feng $\mathrm{Y}$, Wang $\mathrm{X}$, Logan $\mathrm{BE}$ \& Lee $\mathrm{H}$. Brewery wastewater treatment using air - cathode microbial fuel cells. Applied Microbiology and Biotechnology, 2008; 78: 873-880. https://doi.org/10.1007/s00253-008-1360-2 Frankenberg L, Brugna M \& Hederstedt L. Enterococcus faecalis heme - dependent catalase. Journal of Bacteriology, 2002; 184(22): 6351-6356. https://doi. org/10.1128/JB.184.22.6351-6356.2002

24. Gao H, Yang ZK, Barua S, Reed SB, Romine MF, Nealson $\mathrm{KH}$, Fredrickson JK, Tiedje JM \& Zhou J. Reduction 
of nitrate in Shewanella oneidensis depends on a typical NAP and NRF systems with NapB as a preferred electron transport protein from CymA to NapA. The ISME Journal, 2009; 3(8): 966. https://doi. org/10.1038/ismej.2009.40

25. Gil GC, Chang IS, Kim BH, Kim M, Jang JK, Park HS \& Kim HJ. Operational parameters affecting the performannce of a mediator - less microbial fuel cell. Biosensors and Bioelectronics, 2003; 18(4): 327334. https://doi.org/10.1016/S0956-5663(02)00110-0

26. Gorby YA \& Lovley DR. Electron transport in the dissimilatory iron reducer, GS - 15. Applied and Environmental Microbiology, 1991; 57(3): 867-870. https://doi.org/10.1128/AEM.57.3.867-870.1991

27. Gorby YA, Yanina S, Mclean JS, Rosso KM, Moyles D, Dohnalkova A, Beveridge TJ, Chang IS, Kim BH, Kim KS \& Culley DE. Electrically conductive bacterial nanowires produced by Shewanella oneidensis strain MR - 1 and other microorganisms. Proceedings of the National Academy of Sciences, 2006; 103(30): 11358-11363. https://doi.org/10.1073/pnas.0604517103

28. Gurav R, Bhatia SK, Choi TR, Jung HR, Yang SY, Song HS, Park YL, Han YH, Park JY, Kim YG, Choi KY \& Yang YH. Chitin biomass powered microbial fuel cell for electricity production using halophilic Bacillus circulans BBL03 isolated from sea salt harvesting area. Bioelectrochemistry, 2019; 130: 107329. https:// doi.org/10.1016/j.bioelechem.2019.107329

29. Hasegawa Y, Futamata H \& Tashiro Y. Complexities of cell - to - cell communication through membrane vesicles: implications for selective interaction of membrane vesicles with microbial cells. Frontiers in Microbiology, 2015; 6: 633. https://doi.org/10.3389/ fmicb.2015.00633

30. Holkar CR, Arora H, Halder D \& Pinjari DV. Biodegradation of reactive blue 19 with simultaneous electricity generation by the newly isolated electrogenic Klebsiella sp. C NCIM 5546 bacterium in a microbial fuel cell. International Biodeterioration and Biodegradation, 2018; 133: 194-201. https://doi. org/10.1016/j.ibiod.2018.07.011

31. Holmes DE, Bond DR, O'neil RA, Reimers CE, Tender LR \& Lovley DR. Microbial communities associated with electrodes harvesting electricity from a variety of aquatic sediments. Microbial Ecology, 2004; 48(2): 178-190. https://doi.org/10.1007/s00248-003-0004-4

32. Hong G \& Pachter R. Bound Flavin - Cytochrome Model of Extracellular Electron Transfer in Shewanella oneidensis: Analysis by Free Energy Molecular Dynamics Simulations. The Journal of Physical Chemistry B, 2016; 120(25): 5617-5624. https://doi. org/10.1021/acs.jpcb.6b03851

33. Hubenova YV, Rashkov RS, Buchvarov VD, Arnaudova MH, Babanova SM \& Mitov MY. Improvement of yeast biofuel cell output by electrode modifications. Industrial and Engineering Chemistry Research, 2010; 50(2): 557564. https://doi.org/10.1021/ie1000949

34. Hubenova Y \& Mitov M. Extracellular electron transfer in yeast - based biofuel cells: A review. Bioelectrochemistry, 2015a; 106: 177-185. https://doi.org/10.1016/j.bioelechem.2015.04.001

35. Ilamathi R, Sheela AM \& Gandhi NN. Comparative evaluation of Pseudomonas species in single chamber microbial fuel cell with manganese coated cathode for reactive azo dye removal. International Biodeterioration and Biodegradation, 2019; 144: 104744. https://doi.org/10.1016/j.ibiod.2019.104744 36. Ishii SI, Watanabe K, Yabuki S, Logan BE \& Sekiguchi $Y$. Comparison of electrode reduction activities of Geobacter sulfurreducens and an enriched consortium in an air - cathode microbial fuel cell. Applied and Environmental Microbiology, 2008; 74(23): 7348-7355. https://doi.org/10.1128/AEM.01639-08

37. Islam MA, Ethiraj B, Cheng CK, Yousuf A \& Khan MMR. Electrogenic and antimethanogenic properties of Bacillus cereus for enhanced power generation in anaerobic sludge-driven microbial fuel cells. Energy and Fuels, 2017a; 31(6): 6132-6139. https://doi. org/10.1021/acs.energyfuels.7b00434

38. Islam MA, Karim A, Woon CW, Ethiraj B, Cheng CK, Yousuf $A$ \& Khan MMR. Augmentation of air cathode microbial fuel cell performance using wild type Klebsiella variicola. RSC Advances, 2017b; 7(8): 47984805. https://doi.org/10.1039/C6RA24835G

39. Kiely P D, Rader G, Regan JM \& Logan BE. Long - term cathode performance and the microbial communities that develop in microbial fuel cells fed different fermentation endproducts. Bioresource Technology, 2011; 102(1): 361-366. https://doi.org/10.1016/j. biortech.2010.05.017

40. Kim BH, Kim HJ, Hyun MS \& Park DH. Direct electrode reaction of Fe (III) - reducing bacterium, Shewanella putrefaciens. Journal of Microbiology and Biotechnology, 1999; 9: 127-131.

41. Kim HJ, Park HS, Hyun MS, Chang IS, Kim M \& Kim BH. A mediator - less microbial fuel cell using a metal reducing bacterium, Shewanella putrefaciens. Enzyme and Microbial Technology, 2002; 30(2): 145-152. https://doi.org/10.1016/S0141-0229(01)00478-1

42. Kline KA, Dodson KW, Caparon MG \& Hultgren SJ. A tale of two pili: assembly and function of pili in bacteria. Trends in microbiology, 2010; 18(5): 224-232. https://doi.org/10.1016/j.tim.2010.03.002

43. Koch C \& Harnisch F. Is there a specific ecological niche for electroactive microorganisms? ChemElectroChem, 2016; 3(9): 1282-1295. https://doi.org/10.1016/j. tim.2010.03.002

44. Konovalova EY, Stom DI, Zhdanova GO, Yuriev DA, Li Y, Barbora L \& Goswami P. The microorganisms used for working in microbial fuel cells. In AIP Conference Proceedings, 2018; 1952(1): 020017. https://doi. org/10.1063/1.5031979

45. Kopke $M$, Held $C$, Hujer $S$, Liesegang $H$, Wiezer $A$, Wollherr A, Ehrenreich A, Liebl W, Gottschalk G \& Durre P. Clostridium ljungdahlii represents a microbial production platform based on syngas. Proceedings of the National Academy of Sciences, 2010; 107(29): 1308713092. https://doi.org/10.1073/pnas.1004716107

46. Kracke F, Vassilev I \& Kromer JO. Microbial electron transport and energy conservation - the foundation for optimizing bioelectrochemical systems. Frontiers in Microbiology, 2015; 6: 575. https://doi.org/10.1073/ pnas.1004716107

47. Kumar G, Shobana S, Nagarajan D, Lee DJ, Lee KS, 
Lin CY, Chen CY \& Chang JS. Biomass based hydrogen production by dark fermentation - recent trends and opportunities for greener processes. Current Opinion in Biotechnology, 2018; 50: 136-145. https://doi. org/10.1016/j.copbio.2017.12.024

48. Kumari S, Mangwani N \& Das S. Low - voltage producing microbial fuel cell constructs using biofilm - forming marine bacteria. Current Science, 2015; 108(5): 925932.

49. Laspidou CS \& Rittmann BE. Modeling the development of biofilm density including active bacteria, inert biomass, and extracellular polymeric substances. Water Research, 2004; 38(14-15): 33493361. https://doi.org/10.1016/j.watres.2004.04.037

50. $\quad$ Lin T, Ding W, Sun L, Wang L, Liu CG \& Song H. Engineered Shewanella oneidensis - reduced graphene oxide biohybrid with enhanced biosynthesis and transport of flavins enabled a highest bioelectricity output in microbial fuel cells. Nano energy, 2018; 50: 639-648. https://doi.org/10.1016/j.nanoen.2018.05.072

51. Liu T, Yu YY, Chen T \& Chen WN. A synthetic microbial consortium of Shewanella and Bacillus for enhanced generation of bioelectricity. Biotechnology and Bioengineering, 2017; 114(3): 526-532. https://doi. org/10.1002/bit.26094

52. Logan BE. Peer reviewed: extracting hydrogen and electricity from renewable resources. Environmental Science and Technology, 2004; 38(9): 160A-167A. https://doi.org/10.1021/es040468s

53. Logan BE. Simultaneous wastewater treatment and biological electricity generation. Water Science and Technology, 2005; 52(1-2): 31-37. https://doi. org/10.2166/wst.2005.0495

54. Logan BE. Exoelectrogenic bacteria that power microbial fuel cells. Nature Reviews Microbiology, 2009; 7(5): 375-381. https://doi.org/10.1038/ nrmicro2113

55. Logan BE \& Rabaey K. Conversion of wastes into bioelectricity and chemicals by using microbial electrochemical technologies. Science, 2012; 337(6095): 686-690. https://doi.org/10.1126/ science.1217412

56. Logan BE \& Regan JM. Microbial fuel cells - challenges and applications. Environmental Science and Technology, 2006; 40: 5172-5180. https://doi. org/10.1021/es0627592

57 Ogan BE, Hamelers B, Rozendal R, Schroder U, Keller J, Freguia S, Aelterman P, Verstraete W \& Rabaey K. Microbial fuel cells: methodology and technology. Environmental Science and Technology, 2006; 40(17): 5181-5192. https://doi.org/10.1021/ es0605016

58. Lovley DR. Bug juice: harvesting electricity with microorganisms. Nature Reviews Microbiology, 2006; 4(7): 497. https://doi.org/10.1038/nrmicro1442

59. Lovley DR. Happy together: microbial communities that hook up to swap electrons. The ISME Journal, 2017; 11(2): 327. https://doi.org/10.1038/ ismej.2016.136

60. Lovley DR, Giovannoni SJ, White DC, Champine JE, Phillips EJP, Gorby YA \& Goodwin S. Geobacter metallireducens gen. nov. sp. nov., a microorganism capable of coupling the complete oxidation of organic compounds to the reduction of iron and other metals. Archives of Microbiology, 1993; 159(4): 336344. https://doi.org/10.1007/BF00290916

61. Maier TM, Myers JM \& Myers CR. Identification of the gene encoding the sole physiological fumarate reductase in Shewanella oneidensis MR - 1. Journal of Basic Microbiology: An International Journal on Biochemistry, Physiology, Genetics, Morphology, and Ecology of Microorganisms, 2003; 43(4): 312-327. https://doi.org/10.1002/jobm.200390034

62. Malvankar NS, Tuominen MT \& Lovley DR. Biofilm conductivity is a decisive variable for high - current density Geobacter sulfurreducens microbial fuel cells. Energy and Environmental Science, 2012; 5(2): 57905797. https://doi.org/10.1002/jobm.200390034

63. Malvankar NS, Vargas $M$, Nevin KP, Franks AE, Leang C, Kim BC, Inoue K, Mester T, Covalla SF, Johnson JP, Rotello VM, Tuominen MT \& Lovley DR. Tunable metallic - like conductivity in microbial nanowire networks. Nature Nanotechnology, 2011; 6(9): 573. https://doi.org/10.1038/nnano.2011.119

64. Malvankar NS, Vargas M, Nevin K, Tremblay PL, EvansLutterodt K, Nykypanchuk D, Martz E, Tuominen MT \& Lovley DR. Structural basis for metallic - like conductivity in microbial nanowires. MBio, 2015; 6(2): e00084-15. https://doi.org/10.1128/mBio.00084-15

65. Marsili E, Baron DB, Shikhare ID, Coursolle D, Gralnick JA \& Bond DR. Shewanella secretes flavins that mediate extracellular electron transfer. Proceedings of the National Academy of Sciences, 2008; 105(10): 3968-3973. https://doi.org/10.1128/mBio.00084-15

66. Muller V, Imkamp F, Biegel E, Schmidt S \& Dilling S. Discovery of a ferredoxin: $\mathrm{NAD}^{+}$- oxidoreductase (Rnf) in Acetobacterium woodii: a novel potential coupling site in acetogens. Annals of the New York Academy of Sciences, 2008; 1125(1): 137-146. https://doi. org/10.1196/annals.1419.011

67. Myers JM \& Myers CR. Role of the tetraheme cytochrome CymA in anaerobic electron transport in cells of Shewanella putrefaciens MR - 1 with normal levels of menaquinone. Journal of Bacteriology, 2000; 182(1): 67-75. https://doi.org/10.1128/ JB.182.1.67-75.2000

68. Nevin KP, Richter H, Covalla SF, Johnson JP, Woodard TL, Orloff AL, Jia H, Zhang M \& Lovley DR. Power output and columbic efficiencies from biofilms of Geobacter sulfurreducens comparable to mixed community microbial fuel cells. Environmental Microbiology, 2008; 10(10): 2505-2514. https://doi.org/10.1111/ j.1462-2920.2008.01675.x

69. Nevin KP, Woodard TL, Franks AE, Summers ZM \& Lovley DR. Microbial electrosynthesis: feeding microbes electricity to convert carbon dioxide and water to multicarbon extracellular organic compounds. MBio, 2010; 1(2): 00103-10. https://doi. org/10.1128/mBio.00103-10

70. Ni G, Christel S, Roman P, Wong ZL, Bijmans MF \& Dopson $M$. Electricity generation from an inorganic sulfur compound containing mining wastewater by acidophilic microorganisms. Research in microbiology, 2016; 167(7): 568-575. https://doi.org/10.1016/j. 
resmic.2016.04.010

71. Niessen J, Schroder U \& Scholz F. Exploiting complex carbohydrates for microbial electricity generation - a bacterial fuel cell operating on starch. Electrochemistry Communications, 2004; 6(9): 955-958. https://doi. org/10.1016/j.elecom.2004.07.010

72. Nimje VR, Chen CY, Chen CC, Jean JS, Reddy AS, Fan CW, Pan KY, Liu HT \& Chen JL. Stable and high energy generation by a strain of Bacillus subtilis in a microbial fuel cell. Journal of Power Sources, 2009; 190(2): 258-263. https://doi.org/10.1016/j. jpowsour.2009.01.019

73. Okamoto A, Hashimoto K, Nealson KH \& Nakamura $R$. Rate enhancement of bacterial extracellular electron transport involves bound flavin semiquinones. Proceedings of the National Academy of Sciences, 2013; 110(19): 7856-7861. https://doi. org/10.1073/pnas.1220823110

74. Okamoto A, Saito K, Inoue K, Nealson KH, Hashimoto $K$ \& Nakamura R. Uptake of self - secreted flavins as bound cofactors for extracellular electron transfer in Geobacter species. Energy and Environmental Science, 2014; 7(4): 1357-1361. https://doi.org/10.1039/ C3EE43674H

75. Ortega-Martínez AC, Juarez-Lopez K, Solorza-Feria O, Ponce-Noyola MT, Galindez-Mayer J, RinderknechtSeijas N, Poggi-Varaldo HM. Analysis of microbial diversity of inocula used in a five - face parellelpiped and standard microbial fuel cells. International Journal of Hydrogen Energy, 2013; 38(28): 12589-12599. https://doi.org/10.1016/j.ijhydene.2013.02.023

76. Pande $S$, Shitut $S$, Freund L, Westermann $M$, Bertels F, Colesie C, Bischofs IB \& Kost C. Metabolic cross - feeding via intercellular nanotubes among bacteria. Nature communications, 2015; 6: 6238. https://doi.org/10.1038/ncomms7238

77. Pankratova G, Hederstedt L \& Gorton L. Extracellular electron transfer features of Gram -positive bacteria. Analytica Chimica Acta, 2019; 1076: 32-47. https://doi.org/10.1016/j.aca.2019.05.007

78. Pankratova G, Leech D, Gorton L \& Hederstedt L. Extracellular electron transfer by the gram - positive bacterium Enterococcus faecalis. Biochemistry, 2018; 57(30): 4597-4603. https://doi.org/10.1021/acs. biochem. 8 b00600

79. Park DH \& Zeikus JG. Electricity generation in microbial fuel cells using neutral red as an electronophore. Applied and Environmental Microbiology, 2000; 66(4): 1292-1297. https://doi. org/10.1128/AEM.66.4.1292-1297.2000

80. Park HS, Kim BH, Kim HS, Kim HJ, Kim GT, Kim M, Chang IS, Park YK \& Chang HI. A novel electrochemically active and Fe (III) - reducing bacterium phylogenetically related to Clostridium butyricum isolated from a microbial fuel cell. Anaerobe, 2001; 7(6): 297-306. https://doi.org/10.1006/anae.2001.0399

81. Pfeffer C, Larsen S, Song J, Dong M, Besenbacher F, Meyer RL \& Leung KM. Filamentous bacteria transport electrons over centimetre distances. Nature, 2012; 491: 218. https://doi.org/10.1038/nature11586

82. Potter MC. Electrical effects accompanying the decomposition of organic compounds. Proceedings of the Royal Society of London. Series B, Containing Papers of a Biological Character, 1911; 84(571): 260276. https://doi.org/10.1098/rspb.1911.0073

83. Qiao Y, Bao SJ \& Li CM. Electrocatalysis in microbial fuel cells - from electrode material to direct electrochemistry. Energy and Environmental Science, 2010; 3(5): 544-553. https://doi.org/10.1039/ b923503e

84. Qiao Y, Li, CM, Bao SJ, Lu Z \& Hong Y. Direct electrochemistry and electrocatalytic mechanism of evolved Escherichia coli cells in microbial fuel cells. Chemical Communications, 2008; (11): 12901292. https://doi.org/10.1039/b719955d

85. Rabaey K \& Rozendal RA. Microbial electrosynthesis revisiting the electrical route for microbial production. Nature Reviews Microbiology, 2010; 8(10): 706. https://doi.org/10.1038/nrmicro2422

86. Rabaey K, Boon N, Hofte M \& Verstraete W. Microbial phenazine production enhances electron transfer in biofuel cells. Environmental Science and Technology, 2005a; 39(9): 3401-3408. https://doi.org/10.1021/ es048563o

87. Rabaey $K$, Boon N, Siciliano SD, Verhaege M \& Verstraete W. Biofuel cells select for microbial consortia that self - mediate electron transfer. Applied Environmental Microbiology, 2004; 70: 5373-5382. https://doi.org/10.1128/AEM.70.9.5373-5382.2004

88. Rabaey K, Clauwaert P, Aelterman P \& Verstraete W. Tubular microbial fuel cells for efficient electricity generation. Environmental Science and Technology, 2005b; 39(20): 8077-8082. https://doi.org/10.1021/ es050986i

89. Rabaey K, Rodríguez J, Blackall LL, Keller J, Gross P, Batstone D, Verstraete W, Nealson KH. Microbial ecology meets electrochemistry: electricity - driven and driving communities. The ISME Journal, 2007; 1(1): 9-18. https://doi.org/10.1038/ismej.2007.4

90. Reguera G, Mccarthy KD, Mehta T, Nicoll JS, Tuominen MT, Lovley DR. Extracellular electron transfer via microbial nanowires. Nature, 2005; 435: 1098-1101. https://doi.org/10.1038/nature03661

91. Reguera G, Nevin KP, Nicoll JS, Covalla SF, Woodard TL \& Lovley DR. Biofilm and nanowire production leads to increased current in Geobacter sulfurreducens fuel cells. Applied and Environmental Microbiology, 2006; 72(11): 7345-7348. https://doi.org/10.1128/ AEM.01444-06

92. Riccobono G, Pastorella G, Vicari F, D'angelo A, Galia A, Quatrini P \& Scialdone O. Abatement of $\mathrm{AO7}$ in a divided microbial fuel cells by sequential cathodic and anodic treatment powered by different microorganisms. Journal of Electroanalytical Chemistry, 2017; 799: 293-298. https://doi.org/10.1016/j. jelechem.2017.06.003

93. Ringeisen BR, Henderson E, Wu PK, Pietron J, Ray R, Little B, Biffinger JC, Jones-Meehan JM. High power density from a miniature microbial fuel cell using Shewanella oneidensis DSP10. Environmental Science and Technology, 2006; 40: 2629-2634. https://doi. org/10.1021/es052254w

94. Rosenbaum M, Cotta MA \& Angenent LT. Aerated Shewanella oneidensis in continuously fed 
bioelectrochemical systems for power and hydrogen production. Biotechnology and Bioengineering, 2009; 105: 880-888. https://doi.org/10.1002/bit.22621

95. Rosenbaum M, He Z \& Angenent LT. Light energy to bioelectricity: photosynthetic microbial fuel cells. Current opinion in biotechnology, 2010; 21(3): 259264. https://doi.org/10.1016/j.copbio.2010.03.010

96. Ruslan AR \& Vadivelu VM. Nitrite pre - treatment of dewatered sludge for microbial fuel cell application. Journal of Environmental Sciences, 2018; 77: 148-155. https://doi.org/10.1016/j. jes.2018.06.023

97. Safarian S, Rajendran C, Muller H, Preu J, Langer JD, Ovchinnikov S, Hirose T, Kusumoto T, Sakamoto J \& Michel $\mathrm{H}$. Structure of a bd oxidase indicates similar mechanisms for membrane - integrated oxygen reductases. Science, 2016; 352(6285): 583-586. https://doi.org/10.1126/science.aaf2477

98. Schroder U. Anodic electron transfer mechanisms in microbial fuel cells and their energy efficiency. Physical Chemistry Chemical Physics, 2007; 9(21): 2619-2629. https://doi.org/10.1039/B703627M

99. Schuchmann K \& Muller V. Autotrophy at the thermodynamic limit of life: a model for energy conservation in acetogenic bacteria. Nature Reviews Microbiology, 2014; 12(12): 809. https://doi. org/10.1038/nrmicro3365

100. Sekar N, Wu CH, Adams MW \& Ramasamy RP. Electricity generation by Pyrococcus furiosus in microbial fuel cells operated at $90^{\circ} \mathrm{C}$. Biotechnology and Bioengineering, 2017; 114(7): 1419-1427. https:// doi.org/10.1002/bit.26271

101. Sharma Y \& Li B. The variation of power generation with organic substrates in single - chamber microbial fuel cells (SCMFCs). Bioresource Technology, 2010; 101(6): 1844-1850. https://doi.org/10.1016/j. biortech.2009.10.040

102. Shi L, Rosso KM, Zachara JM \& Fredrickson JK. Mtr extracellular electron-transfer pathways in Fe (III) - reducing or Fe (II) - oxidizing bacteria: a genomic perspective. Biochemical Society Transactions, 2012; 40(6): 1261-1267. https://doi.org/10.1042/ BST20120098

103. Shirodkar S, Reed S, Romine M \& Saffarini D. The octahaem SirA catalyses dissimilatory sulfite reduction in Shewanella oneidensis MR - 1. Environmental Microbiology, 2011; 13(1): 108-115. https://doi. org/10.1111/j.1462-2920.2010.02313.x

104. Simpson PJ, Richardson DJ \& Codd R. The periplasmic nitrate reductase in Shewanella: the resolution, distribution and functional implications of two NAP isoforms, NapEDABC and NapDAGHB. Microbiology, 2010; 156(2): 302-312. https://doi.org/10.1099/ mic.0.034421-0

105. Summers ZM, Fogarty HE, Leang C, Franks AE, Malvankar NS \& Lovley DR. Direct exchange of electrons within aggregates of an evolved syntrophic coculture of anaerobic bacteria. Science, 2010; 330(6009): 14131415. https://doi.org/10.1126/science.1196526

106. Suresh KS \& Bulchandani BD. Comparative study of various substrates and microorganisms in a laboratory designed microbial fuel cell. International Journal of Research in Chemistry and Environment (IJRCE), 2012; 2(3): 168-174.

107. Tanaka K, Tamamushi R \& Ogawa T. Bioelectrochemical fuel - cells operated by the cyanobacterium, Anabaena variabilis. Journal of Chemical Technology and Biotechnology. Biotechnology, 1985; 35(3): 191-197. https://doi.org/10.1002/jctb.280350304

108. Tharali AD, Sain N \& Osborne WJ. Microbial fuel cells in bioelectricity production. Frontiers In Life Science, 2016; 9(4): 252-266. https://doi.org/10.1080/215537 69.2016.1230787

109. Thormann KM, Saville RM, Shukla S, Pelletier DA \& Spormann AM. Initial phases of biofilm formation in Shewanella oneidensis MR - 1. Journal of Bacteriology, 2004; 186(23): 8096-8104. https://doi.org/10.1128/ JB.186.23.8096-8104.2004

110. Thurston CF, Bennetto HP, Delaney GM, Mason JR, Roller SD \& Stirling JL. Glucose metabolism in a microbial fuel cell. Stoichiometry of product formation in a thionine - mediated Proteus vulgaris fuel cell and its relation to coulombic yields. Microbiology, 1985; 131(6): 13931401. https://doi.org/10.1099/00221287-131-6-1393

111. Tkach O, Liu L \& Wang A. Electricity generation by Enterobacter sp. of single - chamber microbial fuel cells at different temperatures. Journal of Clean Energy Technologies, 2015; 4(1): 36. https://doi.org/10.7763/ JOCET.2016.V4.250

112. Treesubsuntorn C, Chaiworn W, Surareungchai W \& Thiravetyan P. Increasing of electricity production from Echinodosus cordifolius - microbial fuel cell by inoculating Bacillus thuringiensis. Science of The Total Environment, 2019; 686: 538-545. https://doi. org/10.1016/j.scitotenv.2019.06.063

113. Vellingiri A, Song YE, Munussami G, Kim C, Park C, Jeon BH, Lee SG \& Kim JR. Overexpression of c-type cytochrome, CymA in Shewanella oneidensis MR-1 for enhanced bioelectricity generation and cell growth in a microbial fuel cell. Journal of Chemical Technology \& Biotechnology, 2019; 94(7): 2115-2122. https://doi. org/10.1002/jctb.5813

114. Wang G, Zhang B, Li S, Yang M \& Yin C. Simultaneous microbial reduction of vanadium (V) and chromium (VI) by Shewanella loihica PV - 4. Bioresource Technology, 2017; 227: 353-358. https://doi.org/10.1016/j. biortech.2016.12.070

115. Watson VJ \& Logan BE. Power production in MFCs inoculated with Shewanella oneidensis MR - 1 or mixed cultures. Biotechnology and Bioengineering, 2010; 105: 489-498. https://doi.org/10.1002/bit.22556

116. White GF, Shi Z, Shi L, Wang Z, Dohnalkova AC, Marshall MJ, Fredrickson JK, Zachara JM, Butt JN, Richardson DJ \& Clarke TA. Rapid electron exchange between surface - exposed bacterial cytochromes and Fe (III) minerals. Proceedings of the National Academy of Sciences, 2013; 110(16): 6346-6351. https://doi. org/10.1073/pnas.1220074110

117. Winstedt L, Frankenberg L, Hederstedt L \& Von Wachenfeldt $C$. Enterococcus faecalis V583 contains a cytochrome bd - type respiratory oxidase. Journal of bacteriology, 2000; 182(13): 3863-3866. https://doi. org/10.1128/JB.182.13.3863-3866.2000

118. Wu S, Xiao Y, Wang L, Zheng Y, Chang K, Zheng Z, Yang 
Z, Varcoe JR \& Zhao F. Extracellular electron transfer mediated by flavins in Gram - positive Bacillus sp. WS - XY1 and yeast Pichia stipitis. Electrochimica Acta, 2014; 146: 564-567. https://doi.org/10.1016/j. electacta.2014.09.096

119. Xiao Y, Zhang E, Zhang J, Dai Y, Yang Z, Christensen HE, Ulstrup J \& Zhao F. Extracellular polymeric substances are transient media for microbial extracellular electron transfer. Science Advances, 2017; 3(7): 1700623. https://doi.org/10.1126/sciadv.1700623

120. Yamazaki SI, Kaneko T, Taketomo N, Kano K \& Ikeda T. Glucose metabolism of lactic acid bacteria changed by quinone - mediated extracellular electron transfer. Bioscience, Biotechnology, and Biochemistry 2002; 66: 2100-2106. https://doi.org/10.1271/ bbb. 66.2100
121. Yilmazel YD, Zhu X, Kim KY, Holmes DE \& Logan BE. Electrical current generation in microbial electrolysis cells by hyperthermophilic archaea Ferroglobus placidus and Geoglobus ahangari. Bioelectrochemistry, 2018; 119: 142-149. https://doi.org/10.1016/j. bioelechem.2017.09.012

122. Yong XY, Shi DY, Chen YL, Jiao F, Lin X, Zhou J, Wang SY, Yong YC, Sun YM, Ouyang PK \& Zheng T. Enhancement of bioelectricity generation by manipulation of the electron shuttles synthesis pathway in microbial fuel cells. Bioresource Technology, 2014; 152: 220-224. https://doi.org/10.1016/j.biortech.2013.10.086

123. Zhao CE, Wu J, Ding Y, Wang VB, Zhang Y, Kjelleberg S, Loo JSC, Cao B \& Zhang Q. Hybrid conducting biofilm with built - in bacteria for high - performance microbial fuel cells. ChemElectroChem, 2015; 2(5): 654-658. https://doi.org/10.1002/celc.201402458 